\section{Crabgrass Control and Dollar Spot Suppression in Creeping Bentgrass with DSMA}

\author{
J.M. Goatley, Jr. ${ }^{1}$ \\ Department of Plant and Soil Sciences, Mississippi State University, Mississippi \\ State, MS 39762
}

R.E. Schmidt ${ }^{2}$

Department of Crop and Soil Environmental Sciences, Virginia Polytechnic Institute and State University, Blacksburg, VA 24061

Additional index words. Agrostis stolonifera var. palustris, Digitaria ischaemum, organoarsenical, dollar spot, Lanzia spp., Moellerodiscus spp., disodium methanearsonate Muhl.] control, incidental dollar spot (incited by Lanzia and Moellerodiscus spp.) suppression, and turfgrass quality following sequential, low-level postemergence applications of DSMA to creeping bentgrass (Agrostis stolonifera var. palustris Farwell). DSMA was applied at $22 \mathrm{mg} \cdot \mathrm{m}^{-2}$ at 7-day intervals for 15 consecutive weeks (DSMA-W) from May through Aug. 1986 and 1987 and for 10 consecutive weeks from June through Aug. 1988. DSMA also was applied in three split applications of $110 \mathrm{mg} \cdot \mathrm{m}^{-2}$ every 10 days (DSMA-S) in June and July of each year. DCPA was applied in a single, preemergence application in May as a comparative standard for crabgrass control. Percent crabgrass in either DSMAtreated plot was $20 \%$ by 11 Sept., an infestation that was unacceptable for high-quality turf. Percent crabgrass infestation was $6 \%$ at all rating dates in 1987 or 1988 for DSMAW and $11 \%$ at all dates in 1987 or 1988 for DSMA-S. DCPA significantly reduced percent crabgrass as compared to the nontreated control at all rating dates, but the percent crabgrass ratings tended to be higher than those for either DSMA treatment by the final rating dates of each year. The DSMA treatments significantly reduced dollar spot incidence in each year. Turfgrass discoloration was observed following the DSMA-S treatment in July 1987 as compared to the control, but the turf quality recovered by August. Turfgrass quality was higher for DSMA treatments than for either DCPA or the nontreated control due to season-long crabgrass control and disease suppression. Chemical names used: disodium methanearsonate (DSMA), dimethyl tetrachloroterephthalate (DCPA).

Organoarsenical herbicides, such as DSMA, offer an economical, yet effective, means of postemergence weedy grass control in cool-season turfgrasses, but they frequently cause turfgrass discoloration (Dernoeden and Nash, 1981; Engel and Ilnicki, 1969; Miller and King, 1982; Musser, 1962). Multiple applications of organoarsenicals are necessary to control many annual grass weeds and to reduce turfgrass phytotoxicity (Engel and Ilnicki, 1969; Miller and King, 1982). Turfgrass discoloration is a concern in high-quality turfgrass, particularly creeping bentgrass. A preliminary experiment on creeping bentgrass in June 1985 (unpublished) indicated that DSMA applications at labeled rates of $165 \mathrm{or} 330 \mathrm{mg} \cdot \mathrm{m}^{-2}$ at 10-day intervals provided acceptable postemergence crabgrass control and reduced the incidence of dollar spot. However, objectionable turfgrass discoloration occurred when these levels of DSMA were applied at daytime

\footnotetext{
Received for publication 28 June 1993. Accepted for publicartion 12 Mar. 1994. The cost of publishing this paper was defrayed in part by the payment of page charges. Under postal regulations, this paper therefore must be hereby marked advertisement solely to indicate this fact.

${ }^{1}$ Assistant Professor.

${ }^{2}$ Professor.
}

means $>27 \mathrm{C}$. Therefore, field trials were conducted during the 1986, 1987, and 1988 growing seasons to evaluate turfgrass quality and the efficacy of DSMA applied sequentially at less than the recommended use levels for crabgrass control in creeping bentgrass turf.

\section{Materials and Methods}

The experiments were conducted on a creeping bentgrass turf on a Lodi silt loam soil (typic Hapludult clayey, kaolinitic, mesic family; pH 6.3) at the Turfgrass Research Center, Blacksburg, Va. The turf received N, P, and K each at $49 \mathrm{~kg} \cdot \mathrm{ha}^{-1}$ in mid-May of each year. Turf was mowed three times weekly at a 0.5 cm cutting height and clippings were removed. Plots were irrigated as needed to prevent moisture stress. Crabgrass infestation was natural each year. Different experimental sites were used each year to avoid effects of prior chemical treatment.

DSMA was applied at $22 \mathrm{mg} \cdot \mathrm{m}^{-2}$ for 15 consecutive weeks (DSMA-W) from 15 May through 14 Aug. 1986 and 1987 (330 mg.m ${ }^{-2}$ total applied). In 1988, DSMA-W was applied for 10 consecutive weeks from 13 June through 22 Aug. (220 mg. $\mathrm{m}^{-2}$ total applied) due to late emergence of crabgrass. DSMA also was ap- plied in three split applications every 10 days (DSMA-S) at $110 \mathrm{mg} \cdot \mathrm{m}^{-2} /$ application on 18 and 27 June and 7 July 1986; 18 and 27 June and 7 July 1987; and 20 and 29 June and 9 July 1988. The total amount of DSMA-S delivered was also $330 \mathrm{mg} \cdot \mathrm{m}^{-2}$ each year. The preemergence herbicide DCPA was used as a comparative standard for crabgrass control; it was applied at $1.2 \mathrm{~g} \cdot \mathrm{m}^{-2}$ in a single application on 15 May of each year.

The DSMA-W treatment was initiated when crabgrass first became visible, and DSMA-S application began when crabgrass was in the 1 to 3 tiller stage of development. The treatments were applied to $0.9 \times 1.8$-m plots with a compressed-air boom sprayer delivering aqueous solutions or suspensions of 748 liters $\cdot \mathrm{ha}^{-1}$ at $276 \mathrm{kPa}$.

Percent crabgrass infestation was visually rated periodically in each plot; crabgrass ratings $\geq 20 \%$ were considered unacceptable for high-quality turf. Turfgrass quality was rated on a scale of $1=$ low-quality turf resulting from a combination of crabgrass infestation, discoloration from herbicide treatment, and disease incidence; $6=$ minimum acceptable quality, and $9=$ highest quality turf. The ratings were made relative to the expected aesthetic appearance of high-quality creeping bentgrass turf. Dollar spot disease incidence was rated visually on a scale of $1=$ no disease incidence to 9 $=$ severe turf blighting. The design of each experiment was a randomized complete block with four replications of each treatment. Analyses of variance were performed and treatment means for each variable measured were separated by Fisher's protected LSD test (SAS Institute, 1987).

\section{Results}

Crabgrass infestation. Percent crabgrass infestation was significantly reduced compared to the nontreated control for all chemical treatments at all rating dates in 1986 (Table 1). However, crabgrass infestations were $\geq 20 \%$ by 11 Sept. for all chemical treatments, and control was considered unacceptable for highquality turf. Percent crabgrass was $\leq 6 \%$ at all rating dates in 1987 for DSMA-W and $\leq 11 \%$ for DSMA-S, although there was no significant difference between the two DSMA treatments. While DCPA significantly reduced crabgrass compared to the nontreated control, the infestation was $>20 \%$ by 15 Aug. (Table 1). The herbicidal activity of the DCPA application on 15 May had apparently dissipated by mid-August.

Percent crabgrass infestation in all plots was unexpectedly low in 1988 (Table 1). No crabgrass was observed for DSMA-S at any rating date in 1988, and a rating of only $3 \%$ was recorded for DSMA-W on 5 Sept. Infestation ratings in DCPA-treated plots and the nontreated controls were $9 \%$ and $19 \%$, respectively, by 5 Sept. (Table 1).

Turfgrass quality. Turfgrass quality ratings in 1986 were higher for both DSMA treatments than for the control throughout the experiment(Table 2). Creeping bentgrass quality was similar for the DSMA treatments at 
each rating date, except on 29 Aug., when DSMA-W plots were discolored as a result of the final weekly application of DSMA on 14 Aug. (Table 2). DCPA-treated turf had a higher quality than the control on all dates, except on 14 Oct., when increased crabgrass in DCPAtreated plots resulted in lower quality scores.

Turfgrass quality for the DSMA-S treatment was significantly lower than for DSMA$\mathrm{W}$ at all rating dates in 1987, except 15 Aug. (Table 2). Compared to the control, DSMA-S reduced turfgrass quality through 31 July, but was rated higher on 29 Aug. and 4 Sept. The herbicides.

\begin{tabular}{|c|c|c|c|c|c|}
\hline \multirow{2}{*}{$\begin{array}{l}\text { Rating } \\
\text { date }\end{array}$} & \multicolumn{5}{|c|}{ Treatment $^{2}$} \\
\hline & DSMA-W $^{y}$ & DSMA-S & DCPA & Control & LSD \\
\hline \multicolumn{6}{|c|}{1986} \\
\hline 28 July & $13.3 \mathrm{~b}$ & $13.3 \mathrm{~b}$ & $13.3 \mathrm{~b}$ & $30.0 \mathrm{a}$ & 15.0 \\
\hline 29 Aug. & $10.0 \mathrm{~b}$ & $10.0 \mathrm{~b}$ & $13.3 \mathrm{~b}$ & $36.7 \mathrm{a}$ & 7.5 \\
\hline 11 Sept. & $20.0 \mathrm{~b}$ & $20.0 \mathrm{~b}$ & $30.0 \mathrm{~b}$ & $53.3 \mathrm{a}$ & 20.1 \\
\hline 14 Oct. & $20.0 \mathrm{bc}$ & $13.3 \mathrm{c}$ & $30.0 \mathrm{~b}$ & $53.3 \mathrm{a}$ & 12.0 \\
\hline \multicolumn{6}{|c|}{1987} \\
\hline 9 July & $3.0 \mathrm{~b}$ & $4.7 \mathrm{~b}$ & $8.3 \mathrm{~b}$ & $36.7 \mathrm{a}$ & 8.9 \\
\hline 17 July & $4.0 \mathrm{c}$ & $3.0 \mathrm{c}$ & $15.0 \mathrm{~b}$ & $38.3 \mathrm{a}$ & 6.2 \\
\hline 31 July & $1.7 \mathrm{c}$ & $0.0 \mathrm{c}$ & $18.3 \mathrm{~b}$ & $45.0 \mathrm{a}$ & 8.0 \\
\hline 15 Aug. & $5.3 \mathrm{c}$ & $8.0 \mathrm{c}$ & $28.3 \mathrm{~b}$ & $55.0 \mathrm{a}$ & 13.2 \\
\hline 21 Aug. & $6.3 \mathrm{c}$ & $10.7 \mathrm{bc}$ & $21.0 \mathrm{~b}$ & $55.0 \mathrm{a}$ & 11.1 \\
\hline 4 Sept. & $2.3 \mathrm{c}$ & $6.3 \mathrm{c}$ & $20.0 \mathrm{~b}$ & $51.7 \mathrm{a}$ & 7.7 \\
\hline \multicolumn{6}{|c|}{1988} \\
\hline 1 Aug. & $0.5 \mathrm{~b}$ & $0.0 \mathrm{~b}$ & $1.2 \mathrm{~b}$ & $6.8 \mathrm{a}$ & 5.0 \\
\hline 9 Aug. & $0.5 \mathrm{~b}$ & $0.0 \mathrm{~b}$ & $3.0 \mathrm{~b}$ & $9.8 \mathrm{a}$ & 4.9 \\
\hline 22 Aug. & $0.0 \mathrm{~b}$ & $0.0 \mathrm{~b}$ & $3.8 \mathrm{~b}$ & $13.8 \mathrm{a}$ & 5.9 \\
\hline 5 Sept. & $3.0 \mathrm{bc}$ & $0.0 \mathrm{c}$ & $8.8 \mathrm{~b}$ & $18.8 \mathrm{a}$ & 8.2 \\
\hline
\end{tabular}

${ }^{2}$ DSMA-W applied at $22 \mathrm{mg} \cdot \mathrm{m}^{-2}$ in 15 weekly applications from 13 May to 10 Aug. 1986 and 1987 , and in 10 weekly applications from 13 June to 22 Aug. 1988 ; DSMA-S applied at $110 \mathrm{mg} \cdot \mathrm{m}^{-2}$ in each of three applications on 18 and 27 June and 7 July 1986 and 1987, and on 20 and 29 June and 9 July 1988; DCPA applied at $1.2 \mathrm{~g} \cdot \mathrm{m}^{-2}$ on 15 May.

'Mean separation in rows by Fisher's protected LSD test, $P \leq 0.05$.

Table 2. Quality ratings for creeping bentgrass turf during 3 years following postemergence applications of herbicides.

\begin{tabular}{|c|c|c|c|c|c|}
\hline \multirow{3}{*}{$\begin{array}{l}\text { Rating } \\
\text { date }\end{array}$} & \multicolumn{5}{|c|}{ Ratings $^{2}$} \\
\hline & \multicolumn{5}{|c|}{ Treatment $^{\mathrm{y}}$} \\
\hline & DSMA-W $^{\mathrm{x}}$ & DSMA-S & DCPA & Control & LSD \\
\hline \multicolumn{6}{|c|}{1986} \\
\hline 11 July & $6.7 \mathrm{a}$ & $6.7 \mathrm{a}$ & $5.7 \mathrm{~b}$ & $4.7 \mathrm{c}$ & 0.9 \\
\hline 28 July & $6.0 \mathrm{a}$ & $6.0 \mathrm{a}$ & $5.3 \mathrm{~b}$ & $4.0 \mathrm{c}$ & 0.6 \\
\hline 29 Aug. & $6.0 \mathrm{~b}$ & $7.0 \mathrm{a}$ & $5.0 \mathrm{c}$ & $4.0 \mathrm{~d}$ & 0.8 \\
\hline 11 Sept. & $6.0 \mathrm{a}$ & $6.4 \mathrm{a}$ & $5.0 \mathrm{ab}$ & $4.0 \mathrm{~b}$ & 1.5 \\
\hline 14 Oct. & $6.0 \mathrm{ab}$ & $6.7 \mathrm{a}$ & $5.3 \mathrm{bc}$ & $5.0 \mathrm{c}$ & 0.8 \\
\hline \multicolumn{6}{|c|}{1987} \\
\hline 9 July & $7.0 \mathrm{a}$ & $5.0 \mathrm{c}$ & $7.0 \mathrm{a}$ & $6.0 \mathrm{~b}$ & 0.9 \\
\hline 17 July & $7.0 \mathrm{a}$ & $4.0 \mathrm{~d}$ & $6.0 \mathrm{~b}$ & $5.3 \mathrm{c}$ & 0.6 \\
\hline 31 July & $7.7 \mathrm{a}$ & $5.7 \mathrm{c}$ & $8.0 \mathrm{a}$ & $7.0 \mathrm{~b}$ & 0.9 \\
\hline 15 Aug. & $8.0 \mathrm{a}$ & $7.3 \mathrm{ab}$ & $6.7 \mathrm{ab}$ & $6.0 \mathrm{~b}$ & 1.4 \\
\hline 29 Aug. & $8.3 \mathrm{a}$ & $7.3 \mathrm{~b}$ & $6.3 \mathrm{c}$ & $6.3 c$ & 0.8 \\
\hline 4 Sept. & $8.3 \mathrm{a}$ & $6.7 \mathrm{~b}$ & $6.0 \mathrm{c}$ & $5.0 \mathrm{c}$ & 0.7 \\
\hline \multicolumn{6}{|c|}{1988} \\
\hline 22 June & $8.8 \mathrm{a}$ & $7.2 \mathrm{~b}$ & $8.0 \mathrm{ab}$ & $8.2 \mathrm{ab}$ & 1.2 \\
\hline 11 July & 7.5 & 7.0 & 6.8 & 6.8 & NS \\
\hline 26 July & $7.2 a b$ & $7.5 \mathrm{a}$ & $6.0 \mathrm{~b}$ & $6.2 \mathrm{ab}$ & 1.4 \\
\hline 9 Aug. & $7.0 \mathrm{ab}$ & $6.2 \mathrm{bc}$ & $5.8 \mathrm{bc}$ & $5.2 \mathrm{c}$ & 1.3 \\
\hline 22 Aug. & $7.5 \mathrm{ab}$ & $6.5 \mathrm{ab}$ & $5.8 \mathrm{bc}$ & $4.8 \mathrm{c}$ & 1.6 \\
\hline 5 Sept. & $7.2 \mathrm{ab}$ & $6.5 \mathrm{bc}$ & $5.8 \mathrm{bc}$ & $4.8 \mathrm{c}$ & 2.0 \\
\hline
\end{tabular}

${ }^{2}$ Turfgrass quality scale: $1=$ low-quality turf as a result of crabgrass infestation, herbicide phytotoxicity, or disease incidence; $6=$ minimal acceptable turfgrass quality; $9=$ highest quality turf.

yDSMA-W applied weekly at $22 \mathrm{mg} \cdot \mathrm{m}^{-2}$ from 13 May to 10 Aug. 1986 and 1987, and from 13 June to 22 Aug. 1988; DSMA-S applied at $110 \mathrm{mg} \cdot \mathrm{m}^{-2}$ in each of three applications on 18 and 27 June and 7 July 1986 and 1987, and on 20 and 29 June and 9 July 1988; DCPA applied at $1.2 \mathrm{~g} \cdot \mathrm{m}^{-2}$ on 15 May.

${ }^{x}$ Mean separation in rows by Fisher's protected LSD test, $P \leq 0.05$.

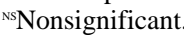

discoloration from the weekly $22 \mathrm{mg}$ DSMA/ $\mathrm{m}^{2}$ treatments compared to three applications of $110 \mathrm{mg} \cdot \mathrm{m}^{-2}$ at 10 -day intervals.

Quality ratings in 1988 were similar for all treatments through 26 July, primarily as a result of no crabgrass in the plots (Table 2). DSMA-W-treated plots were rated significantly higher than DSMA-S plots on 22 June because of turfgrass discoloration from the 20 June application of $110 \mathrm{mg}$ DSMA $/ \mathrm{m}^{2}$. DSMA$\mathrm{W}$ plots were rated higher than the control on 22 Aug. and 5 Sept. as a result of crabgrass control and dollar spot suppression.

Dollar spot control. A nontarget effect of dollar spot disease suppression by DSMA treatments was evident in each year (Table 3 ). During 1986, the DSMA-S treatment consistently had the lowest disease ratings through 11 Sept. This result indicated that the disease suppression activity of DSMA-S apparently continued through the summer, although the final application of the split treatment was made on 7 July (Table 3). DSMA-W provided significant dollar spot reduction through 29 Aug., but its effect did not differ from the nontreated control thereafter. DCPA-treated plots had lower dollar spot ratings than the nontreated control on 11 July and 29 Aug.

In 1987, DSMA-W plots had significantly less dollar spot than the control on all dates except 15 Aug. (Table 3). DSMA-S-treated plots received significantly lower disease ratings than the control through 31 July. However, no further disease reduction was recorded after this date, which indicates that the disease suppression activity had dissipated. DCPA plots had significantly lower dollar spot ratings than the control through 17 July. For 1988, there was no significant difference in disease ratings between any treatments on 22 June, but DSMA-W had less disease incidence on 11 July and 9 Aug., and DSMA-S on 11 and 26 July (Table 3).

\section{Discussion}

While little work has been done to verify fungicidal activity of organoarsenical compounds, evidence does support the concept that these compounds might have fungicidal activity (Sijpesteijn et al., 1969). However, further research is necessary to test this hypothesis.

Creeping bentgrass is known to be very susceptible to dollar spot (Couch, 1973). By controlling crabgrass, DSMA might have further reduced the occurrence of dollar spot by removing another potential host, but this explanation needs further evaluation. This research showed no clear indication that crabgrass served as a primary host for Lanzia and Moellerodiscus spp., as indicated by the crabgrass and dollar spot ratings of 1988 (Tables 1 and 3). In 1988, crabgrass infestation was low in DSMA-treated plots, while dollar spot ratings were higher than in 1986 and 1987 (Tables 1 and 3). If crabgrass control had been a primary means of eliminating a host of the causal agents of dollar spot, then dollar spot ratings likewise would have been low. Additional research is necessary to determine what 
Table 3. Ratings for dollar spot on creeping bentgrass during 3 years following postemergence applications of herbicides.

\begin{tabular}{llllll}
\hline \hline & \multicolumn{5}{c}{ Disease rating $^{2}$} \\
\cline { 2 - 6 } Rating & \multicolumn{5}{c}{ Treatment $^{\mathrm{y}}$} \\
\cline { 2 - 6 } date & DSMA-W & DSMA-S & DCPA & Control & LSD \\
\hline & & & 1986 & & \\
11 July & $2.7 \mathrm{c}$ & $1.7 \mathrm{c}$ & $4.7 \mathrm{~b}$ & $6.7 \mathrm{a}$ & 1.7 \\
28 July & $2.7 \mathrm{~b}$ & $2.0 \mathrm{~b}$ & $4.0 \mathrm{ab}$ & $6.0 \mathrm{a}$ & 2.2 \\
29 Aug. & $3.7 \mathrm{c}$ & $2.0 \mathrm{~d}$ & $5.3 \mathrm{~b}$ & $7.0 \mathrm{a}$ & 0.8 \\
11 Sept. & $4.7 \mathrm{a}$ & $2.3 \mathrm{~b}$ & $6.0 \mathrm{a}$ & $6.0 \mathrm{a}$ & 1.9 \\
14 Oct. & $4.3 \mathrm{a}$ & $3.0 \mathrm{~b}$ & $4.0 \mathrm{ab}$ & $3.3 \mathrm{ab}$ & $\mathrm{N}$ \\
& & & & & \\
9 July & $2.7 \mathrm{~b}$ & $1.7 \mathrm{c}$ & $2.3 \mathrm{~b}$ & $3.7 \mathrm{a}$ & 0.6 \\
17 July & $2.3 \mathrm{c}$ & $2.7 \mathrm{c}$ & $4.0 \mathrm{~b}$ & $5.3 \mathrm{a}$ & 0.7 \\
31 July & $1.0 \mathrm{~b}$ & $1.0 \mathrm{~b}$ & $1.7 \mathrm{ab}$ & $2.3 \mathrm{a}$ & 0.7 \\
15 Aug. & $2.1 \mathrm{~b}$ & $5.0 \mathrm{a}$ & $4.0 \mathrm{ab}$ & $2.5 \mathrm{~b}$ & 1.6 \\
29 Aug. & $1.3 \mathrm{c}$ & $4.7 \mathrm{a}$ & $4.3 \mathrm{ab}$ & $3.3 \mathrm{~b}$ & 1.3 \\
4 Sept. & $1.3 \mathrm{~b}$ & $4.7 \mathrm{a}$ & $4.0 \mathrm{a}$ & $3.0 \mathrm{ab}$ & 1.8 \\
& & & & & \\
22 June & 3.0 & 3.5 & 2.8 & 2.8 & NS \\
11 July & $3.0 \mathrm{~b}$ & $2.8 \mathrm{~b}$ & $4.2 \mathrm{a}$ & $4.2 \mathrm{a}$ & 1.1 \\
26 July & $4.0 \mathrm{ab}$ & $3.8 \mathrm{~b}$ & $4.8 \mathrm{ab}$ & $6.0 \mathrm{a}$ & 1.8 \\
9 Aug. & $3.5 \mathrm{~b}$ & $4.8 \mathrm{ab}$ & $5.2 \mathrm{a}$ & $6.0 \mathrm{a}$ & 1.4 \\
22 Aug. & $2.5 \mathrm{c}$ & $4.3 \mathrm{ab}$ & $5.0 \mathrm{ab}$ & $5.8 \mathrm{a}$ & 1.7 \\
5 Sept. & $1.8 \mathrm{~b}$ & $4.8 \mathrm{a}$ & $4.8 \mathrm{a}$ & $5.2 \mathrm{a}$ & 1.8 \\
\hline
\end{tabular}

${ }^{2}$ Dollar spot disease scale: $1=$ no sign of disease, $9=$ severe turf blighting.

yDSMA-W applied weekly at $22 \mathrm{mg} \cdot \mathrm{m}^{-2}$ from 13 May to 10 Aug. 1986 and 1987, and from 13 June to 22 Aug. 1988; DSMA-S applied at $110 \mathrm{mg} \cdot \mathrm{m}^{-2}$ in each of three applications on 18 and 27 June and 7 July 1986 and 1987, and on 20 and 29 June and 9 July 1988; DCPA applied at $1.2 \mathrm{~g} \cdot \mathrm{m}^{-2}$ on 15 May.

${ }^{x}$ Mean separation in rows by Fisher's protected LSD test, $P \leq 0.05$.

${ }^{\text {ss }}$ Nonsignificant.

role crabgrass control might play in suppressing dollar spot.

We cannot explain the limited but significant dollar spot suppression observed from DCPA treatment; however, the possibility exists that the disease suppression was somehow related to controlling crabgrass, as previously discussed.

Compared to three split DSMA applications at manufacturer-suggested use levels, sequential DSMA applications at reduced levels acceptably reduced crabgrass infestation in two out of the three years while lessening turfgrass discoloration. Turfgrass quality from both DSMA treatments was generally improved compared to the nontreated control or DCPA due to reduced crabgrass infestation and dollar spot suppression. The possibility existed for turfgrass discoloration following treatment during hot weather, as evidenced by the phytotoxicity from DSMA-S application in July 1987 . However, quality ratings for the DSMA-W treatment never dropped below the minimum acceptable rating of 6 , and the DSMA-S treatment performed similarly in both 1986 and 1988. While DSMA treatment did not fully control dollar spot, the disease suppression was a desirable nontarget effect that improved turf quality.

The feasibility of low-level, weekly DSMA applications for smooth crabgrass control will not meet the management programs of all turfgrass professionals and must be considered on an individual basis. The increases in labor, time, and applicator exposure from weekly DSMA applications are factors that must be judged, as well as the increased potential of environmental problems from mishandling the herbicide. However, a carefully planned program of weekly, low-level, DSMA applications offers the desirable prospect of applying only a small dosage of the chemical as it is needed, thus avoiding undesirable turfgrass phytotoxicity. Obviously, treatment can be omitted or stopped if the crabgrass infestation is not sufficient to justify chemical application. This possibly could have been the case in the 1988 trial when crabgrass infestation was inherently low. Furthermore, using postemergence herbicides on a curative basis offers the advantage of targeting only the weed-infested areas, rather than making preventive, large-scale, preemergence herbicide applications.

\section{Literature Cited}

Couch, H.B. 1973. Sclerotinia dollar spot, p. 51-55. In: Diseases of turfgrasses. 2nd ed. Robert E. Krieger Publishing Co., Malabar, Fla.

Dernoeden, P.H. and J.A. Grande. 1983. Post-emergence control of crabgrass in turf with MSMA and HOE-581. Proc. Annu. Mtg. Northeast. Weed Sci. Soc. 37:384-388

Dernoeden, P.H. and A.S. Nash. 1981. Effects of excessive levels of some postemergent crabgrass herbicides on Tufcote bermudagrass and Penncross creeping bentgrass. Proc. Annu. Mtg. Northeast. Weed Sci. Soc. 35:337-341.

Engel, R.E. and R.D. Ilnicki. 1969. Turf weeds and their control, p. 240-287. In: A.A. Hanson and F.V. Juska (eds.). Turfgrass science. Monogr. 14. Amer. Soc. Agron., Madison, Wis.

Miller, E.M. and J.W. King. 1982. Postemergence herbicide control of crabgrass in three turf species. Agron. Abstr. Amer. Soc. Agron. p. 144.

Musser, H.B. 1962. Turf management. McGrawHill, New York. p. 197.

SAS Institute. 1987. SAS user's guide: Statistics. 1987 ed. SAS Inst., Cary, N.C.

Sijpesteijn, A.K., J.G.A. Luitjen, and G.J.M. Van der Kerk. 1969. Organometallic fungicides, p. 331-362. In: D.C. Torgeson (ed.). FungicidesAn advanced treatise. vol. II. Academic, New York. 